\title{
Estuarine habitat evaluation measured by growth of juvenile summer flounder Paralichthys dentatus in a North Carolina estuary
}

\author{
Ann Marie D. Necaise ${ }^{1, *}$, Steve W. Ross ${ }^{1}$, John M. Miller ${ }^{2}$ \\ ${ }^{1}$ Center for Marine Science, University of North Carolina at Wilmington, 5600 Marvin K. Moss Lane, Wilmington, \\ North Carolina 28409, USA \\ ${ }^{2}$ Department of Zoology, North Carolina State University, Campus Box 7617, Raleigh, North Carolina 27695, USA
}

\begin{abstract}
Habitat quality and fish success, in terms of growth and mortality, are presumably correlated, and abiotic conditions are likely to be a major component in determining habitat quality. We assessed habitat quality in terms of fish growth and mortality using basic abiotic factors as the major variables. Juvenile summer flounder Paralichthys dentatus (42 to $59 \mathrm{~mm}$ total length) were caged at 5 sites in and around Masonboro Island, North Carolina, USA, during June and July 1999. Temperature, dissolved oxygen, salinity and $\mathrm{pH}$ were recorded every $30 \mathrm{~min}$ at each enclosure site during the experiment. Potential predators were excluded by cages and known quantities of food were provided to reduce potential impacts of food availability. Fish were individually tagged, and growth rates calculated for surviving fish. Abiotic conditions varied significantly among sites, although no differences in growth rates were detected among sites. Variability in growth rates both within and among sites was high, with 1 site experiencing total mortality. Results suggest that basic abiotic conditions, at the levels and durations that occur within a southeastern US estuary during summer, have little impact on juvenile summer flounder growth, but may influence survival.
\end{abstract}

KEY WORDS: Habitat evaluation · Habitat quality $\cdot$ Abiotic factors $\cdot$ Growth rates $\cdot$ Summer flounder Water quality

\section{INTRODUCTION}

The importance of habitat protection in maintaining fisheries resources has received increasing attention in recent years. The success of many marine species depends on the survival of estuarine-dependent early life history stages; therefore, management efforts to maintain or enhance recruitment to a fishery may best be focused within estuaries. Correct identification, evaluation, characterization and an understanding of the functions of these environments are essential for efficient fisheries management, especially if management options include stock enhancement or habitat protection (Guindon \& Miller 1995).

Correct evaluation of fish habitat quality in estuaries is difficult due to the dynamic nature of these environ- ments and our inability to determine the exact physiological relevance of 'habitat quality' to fishes. Often, habitat evaluation is based on fish abundance or presence/absence data. Environmental conditions vary constantly throughout an estuary, and juvenile estuarine fishes can vary their distribution in response to such variations. Therefore, measuring densities or abundance of mobile fauna in a dynamic habitat can lead to misleading inferences about habitat preference, unless intense sampling efforts are made (Neill \& Gallaway 1989, Able 1999, Miller et al. 2000). Guindon \& Miller (1995) demonstrated that southern flounder Paralichthys lethostigma caged in underutilized habitats grew significantly faster than those caged in fully utilized habitats. They suggested that spatial and temporal patterns in recruitment played an important role in determining 
habitat utilization, and that assessing habitat in terms of potential rather than realized productivity would prevent under-assessment of habitat value during years of low colonization. Nominal habitat classifications may also be insufficient. Phelan et al. (2000) were unable to detect growth differences across 5 habitat types within and among 3 estuaries, and concluded that such broad classifications did not adequately define valuable habitat requirements for some species.

Abiotic factors, which comprise one component of a habitat, can affect growth rates of juvenile fishes. Since rapid growth may provide a selective size advantage for juvenile fishes (Sogard 1992, Van der Veer et al. 1994) and growth rates may vary as a function of habitat, the value of estuarine nursery habitats may vary as a function of factors that influence growth, such as abiotic characteristics. Several laboratory studies have focused on the individual, and occasionally combined, effects of factors such as temperature, salinity, dissolved oxygen and food availability on feeding and growth rates of juvenile flatfishes (Peters \& Anglovic 1973, Malloy \& Targett 1991, 1994, Reichert \& Van Der Veer 1991, Davis 1998, Taylor \& Miller 2001). Cage enclosure studies of juvenile flatfishes have been used to correlate growth with continuous temperature measurements, as well as other habitat variables (Sogard 1992, Guindon \& Miller 1995). Model simulations have also been used to predict growth rates under in situ temperature, salinity, dissolved oxygen and $\mathrm{pH}$ regimes (Miller et al. 2000). These studies have helped to clarify the effects of certain abiotic factors on the growth of juvenile fishes. Few studies, however, have focused on the effect of natural fluctuations in several abiotic factors acting together on growth rates.

To understand how fishes respond to a given habitat, the abiotic factors characterizing their habitat must be well-defined and measured at time scales relevant to the physiology of the fishes. The interactions between shortterm variability in abiotic parameters and fish growth are poorly known. Historically, abiotic parameters have been measured separately, or by taking periodic point samples over wide spatial and temporal scales (Summers \& Engle 1993). Such methods provide limited information on the type and magnitude of environmental variability actually experienced by fishes occupying a habitat. Current technology enables continuous monitoring on much shorter time scales and is more relevant to the interactions of biota with the physical environment (Wenner \& Geist 2001, Wenner et al. 2001).

Our objective in the present study was to evaluate habitat quality in terms of the effects of basic abiotic factors on growth of estuarine-dependent, juvenile, summer flounder Paralichthys dentatus. We determined short-term growth rates by enclosure experiments in estuarine habitats with different abiotic re- gimes, identical food availability and no predation. Different growth rates of caged juveniles in creeks with different abiotic regimes would suggest responses to abiotic conditions, while similar growth rates would suggest that factors other than abiotic conditions drive differences in growth rates. Mortality rates were also taken into consideration when estimateing production (Wooten 1992, Gibson 1994, Guindon \& Miller 1995). Differences among sites would thus reflect both growth and mortality.

\section{MATERIALS AND METHODS}

Site selection. Cage enclosures were placed in and adjacent to Masonboro Island, a barrier island in the North Carolina National Estuarine Research Reserve. Masonboro Island is located approximately $8 \mathrm{~km}$ east of Wilmington and is bordered by the Atlantic Ocean on the east and the Intracoastal Waterway on the west (Fig. 1). Based on preliminary data collected from 8 to 21 June 1999 with YSI 6000 dataloggers, we selected 5 sites, representing a range of abiotic conditions. Sites M1, M2 and M3 were located within the marsh system of Masonboro Island; M1 and M2 were in the deepest sections of a shallow, narrow creek, and M3 was in a wide creek channel. Sites L1 and L2 were located in mainland creeks (Hewlett and Howe Creeks) west of Masonboro Island. Both mainland creeks received a large amount of upland drainage, whereas the Masonboro Island sites received none. All sites were shallow (average depth about $1 \mathrm{~m}$ ) and influenced by semidiurnal tides (Thurman 1987). The substrate at each site was visually characterized as a predominately sand-mud mixture. Marsh-edge vegetation was dominated by the smooth cordgrass Spartina alterniflora.

Abiotic measurements. YSI 6000 remote dataloggers were used to measure salinity, temperature, $\mathrm{pH}$ and dissolved oxygen (DO) at 30 min intervals at each enclosure site for the duration of the experiment. Dataloggers were checked against a hand-held YSI 85 in the field to ensure accurate operation. Upon completion of the experiment, the dataloggers were removed from the field for post-deployment calibration checks and data downloading.

Bartlett's test for homogeneity of variances was used to determine if the variances of each of the abiotic parameters were the same for each site (Zar 1999). If variances were heteroscedastic, the data were logtransformed prior to analysis of variance (Zar 1999). A 1 -way ANOVA was used to determine if abiotic parameters were the same across sites (Zar 1999). If the outcome was significant, Tukey's Honestly Significant Difference (HSD) test determined which creeks were the most similar. 


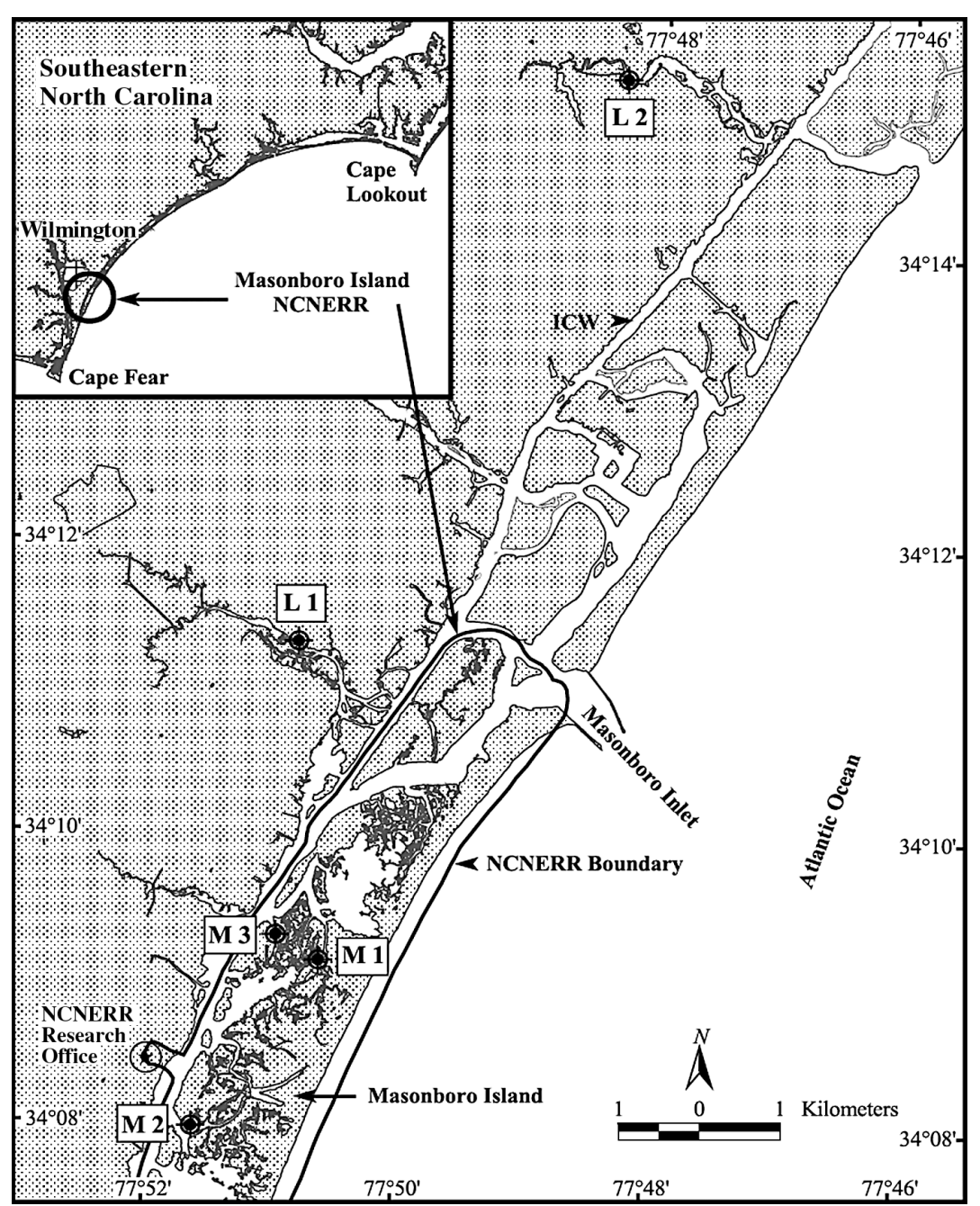

Fig. 1. Enclosure sites in and around Masonboro Island, North Carolina, USA, in part of the North Carolina National Estuarine Research Reserve (NCNERR) system. ICW: Intracoastal Waterway ment type and fish movement during tidal cycles, were controlled by the experimental design, further isolating the effect of abiotic conditions on growth.

Hatchery fishes reared on pellets can take 7 to $14 \mathrm{~d}$ before they begin to consume wild food (R. Vega pers. comm.). Pelleted commercial feed (on which our fish had been reared) was provided to ensure that growth rates were not affected by the inability of hatchery fish to acquire wild prey and to prevent food from becoming a limiting factor during the enclosure study. Food was provided daily at slack tide at $50 \times$ the ad libitum feeding rate to ensure that an adequate amount remained in the cage and was available to the fish despite currents and turbulence.

We deployed 4 cages at each of the 5 sites. The cages were constructed of $6.35 \mathrm{~mm}$ polyethylene mesh reinforced with PVC tubing. They were cylindrical in shape (1 $\mathrm{m}$ in diameter, $0.5 \mathrm{~m}$ in height) and completely enclosed. The bottom of each cage was pushed into the first few centimeters of sediment and the entire structure was anchored with cement blocks between 2 metal $(2 \mathrm{~m})$ posts. The cages were completely submerged at low tide. Because of increased fouling during the summer months, the cages were regularly cleaned with stiff brushes to maintain water flow.

Enclosure experiments. To examine the impact of abiotic factors on growth, juvenile summer flounder were caged during the summer, a period of estuarine utilization and rapid growth (Burke et al. 1991, Roundtree \& Able 1992, Szedlmayer et al. 1992, Burke 1995, Able \& Fahay 1998). A major objective of these experiments was to control for as many variables as possible so that basic abiotic conditions would comprise the dominant influence on growth. We used summer flounder juveniles from Great Bay Aquafarms (New Hampshire) rather than wild-caught North Carolina fish to ensure that (1) all specimens were of similar genetic composition, (2) fish were of similar size and age, (3) history prior to enclosure in the cages was known, and (4) that fish were readily and predictably available at the start of the experiment. Additional variables, including food availability, predation, sedi-
Summer flounder were stocked at densities of 4 fish per cage, based on similar enclosure experiments (Guindon \& Miller 1995, Kellison 2000, Duchon 2001). Individuals were measured (nearest $\mathrm{mm}$, total length, TL), weighed (nearest $0.01 \mathrm{~g}$ ) and subcutaneously injected with acrylic paint (as individual tags) prior to stocking. Initial mean $( \pm \mathrm{SD})$ length and weight of fish (spawned March 1999) per site ranged from $50 \pm 2.51$ to $53 \pm$ $2.84 \mathrm{~mm}$ TL and $1.22 \pm 0.16$ to $1.81 \pm 0.39 \mathrm{~g}$ (Table 1 ). There were no significant differences in mean initial lengths or weights of fish among sites (ANOVA, $p=0.71$ and 0.82). Fish were held in cages for $3 \mathrm{wk}$ (29 June to 22 July 1999), based on similar laboratory and enclosure experiments measuring short-term growth rates (Sogard 1992, Guindon \& Miller 1995, Kellison 2000, Duchon 2001, Taylor \& Miller 2001). At the end of the enclosure experiment, the fish were recovered from 
Table 1. Paralichthys dentatus. Mean (SD) initial and final total lengths (TL, mm), weights (WT, g), mean growth $\mathrm{d}^{-1}$ in length (TL mm) and weight (WT g) and mean growth rates (\% TL $\mathrm{mm} \mathrm{d}^{-1}, \% \mathrm{WT} \mathrm{g} \mathrm{d}^{-1}$ ) in enclosure experiments (Masonboro Island, North Carolina, 29 June to 22 July 1999). Final measurements not available for M2 (zero recovery of fish). $n=4$ for each site

\begin{tabular}{|c|c|c|c|c|c|c|c|c|}
\hline \multirow[t]{2}{*}{ Site } & \multicolumn{2}{|c|}{ — Length — } & \multicolumn{2}{|c|}{$\longrightarrow$ Weight $ـ$} & \multicolumn{2}{|c|}{ Growth $\left(\mathrm{d}^{-1}\right)$} & \multicolumn{2}{|c|}{ - Growth rate $\left(\% \mathrm{~d}^{-1}\right)$ - } \\
\hline & Initial & Final & Initial & Final & $\mathrm{TL}$ & WT & $\mathrm{TL}$ & WT \\
\hline L1 & $51(0.86)$ & $57(1.55)$ & $1.39(0.08)$ & $1.99(0.27)$ & $0.27(0.09)$ & $0.03(0.01)$ & $0.50(0.16)$ & $1.63(0.53)$ \\
\hline L2 & $52(0.47)$ & $57(1.53)$ & $1.43(0.10)$ & $2.27(0.32)$ & $0.24(0.06)$ & $0.04(0.01)$ & $0.43(0.09)$ & $2.04(0.56)$ \\
\hline M1 & $53(2.84)$ & $58(2.12)$ & $1.81(0.39)$ & $1.60(0.14)$ & $0.11(0.09)$ & $-0.01(0.03)$ & $0.21(0.18)$ & $-0.49(1.79)$ \\
\hline M2 & $50(2.51)$ & & $1.22(0.16)$ & & & & & \\
\hline M3 & $51(1.97)$ & $53(1.26)$ & $1.37(0.16)$ & $1.58(0.14)$ & $0.13(0.08)$ & $0.01(0.01)$ & $0.24(0.01)$ & $0.17(0.65)$ \\
\hline
\end{tabular}

the cages, measured, weighed and subsequently preserved in $10 \%$ formalin. They were later transferred to $40 \%$ isopropyl alcohol for stomach content analysis.

Since no fish were recoverd from the cages at Site M2 on 22 July (see beginning of 'Results'), we ran 2 additional enclosure experiments on 26 to 27 and 28 to 29 July 1999. Prior to these trials, each cage was carefully examined for holes in the mesh. Each additional experiment was $24 \mathrm{~h}$ in duration.

Growth rate. In juvenile fishes, change in weight is a more sensitive indicator of growth than change in length (Guindon \& Miller 1995); therefore, mean ( \pm SD) instantaneous rate of growth in weight $(G)$ was used:

$$
G=\frac{\left(\ln W_{\mathrm{f}}-\ln W_{\mathrm{i}}\right)}{t} \times 100
$$

where $W_{\mathrm{f}}$ is final weight, $W_{\mathrm{i}}$ is initial weight of the fish at the time of caging and $t$ is duration of the trial in days. For comparison with similar studies, mean $( \pm \mathrm{SD})$ instantaneous rate of growth in length was also calculated. A fixed-effects, nested ANOVA model was used to test the effects of site and initial weight on final weight. Fish were pooled by cage. Sites were considered fixed variables, and cages, fish and their interactions random variables. When differences in growth were found among sites, a multiple regression was used to assess the relationship between abiotic factors and growth.

Production analysis. Following completion of the enclosure experiment, production $(P)$ for each cage was calculated as:

$$
P=B \times \exp (G-Z)
$$

where $B$ is initial biomass, $G$ is instantaneous rate of growth in weight and $Z$ is mortality rate. Differences in production among sites were determined using a 1-way ANOVA.

Stomach contents. The stomach contents of caged fish were examined at the end of the experiment. Contents were identified as artificial or natural prey. Gut fullness was assessed by assigning a variable from 0 to 2 to each fish, where $0=$ completely empty stomachs, 2 = full stomachs and 1 = intermediate fullness. This range was based on preliminary examinations that revealed guts were either empty or extremely full, with very few intermediate levels of fullness. Differences in gut fullness among sites were tested using a chisquare test on the proportions of fish with prey in their stomachs.

\section{RESULTS}

\section{Abiotic data}

The cages were checked 2 wk after beginning the experiment at each site. No fish were found in any of the cages at Site M2, and the cages and the YSI datalogger were removed from this site. Therefore, abiotic information (except DO) for Site M2 is only available for the first $2 \mathrm{wk}$ of the experiment. The oxygen probe also failed at Site M2, preventing DO comparisons between Site M2 and the other sites.

Water temperatures ranged from 23.4 to $36.2^{\circ} \mathrm{C}$ during the $3 \mathrm{wk}$ trial, with site means of 26.9 to $29^{\circ} \mathrm{C}$ (Fig. 2, Table 2). Maximum water temperatures ranged from 32.8 to $36.2^{\circ} \mathrm{C}$ among sites. Site M3 displayed both the maximum and minimum temperatures recorded during the experiment. DO ranged from 0.0 to $10.9 \mathrm{mg} \mathrm{l}^{-1}$, with site means between 4.6 and $6.9 \mathrm{mg} \mathrm{l}^{-1}$ (Table 2). DO varied in range and pattern across sites, with abrupt fluctuations occurring at each site (Fig. 3). At Site L2, for example, DO levels rose from 0.2 to $4.5 \mathrm{mg} \mathrm{l}^{-1}$ in $1 \mathrm{~h}$ and from 1.6 to $5.0 \mathrm{mg} \mathrm{l}^{-1}$ in $1.5 \mathrm{~h}$. Salinity ranged from 0.1 to $36.4 \mathrm{ppt}$ among sites, with site means of 23.1 to $29.8 \mathrm{ppt}$, and showed diverse tidal fluctuations among sites (Fig. 4, Table 2). For example, salinity at Site L2 rose from 1.5 to $28.0 \mathrm{ppt}$ in $3.5 \mathrm{~h}$; such patterns were frequent among sites throughout the experiment. pH ranged from 6.8 to 8.5 , with site means of 7.2 and 7.8 (Fig. 5, Table 2).

Since variances in abiotic factors differed, data were log-transformed prior to ANOVA testing. There were statistically significant differences in means of temperature, DO, salinity and $\mathrm{pH}$ measurements among all sites (ANOVA, p $\leq 0.0001$, all factors). The variances of abiotic factors also differed among sites (Bartlett's test, 
$\mathrm{p} \leq 0.001$, all factors). The 2 mainland creeks (L1 and L2) had similar variances in salinity regimes (Tukey's HSD, $\mathrm{p}<0.05$ ), as did 2 barrier island creeks (M1 and M3) (Tukey's HSD, $p<0.05$ ). There were no similarities in variances of temperature, $\mathrm{DO}$ or $\mathrm{pH}$ among sites.

Hypoxic events, defined as DO concentrations $\leq 2.0 \mathrm{mg} \mathrm{l}^{-1}$ (Diaz \& Rosenberg 1995), occurred at each of the enclosure sites, and ranged in number from 1 to
24 , with maximum durations ranging from 6 to $17 \mathrm{~h}$ (Table 3). For the 3 sites with more than 1 event, there was no significant difference in the mean duration of hypoxic events (ANOVA, $p=0.27$ ). Hyperoxic events, defined for our purposes as DO saturation $\geq 110 \%$, also occurred at each of the enclosure sites. The number of events among sites ranged from 5 to 22 (Table 3). There was a significant difference in the mean
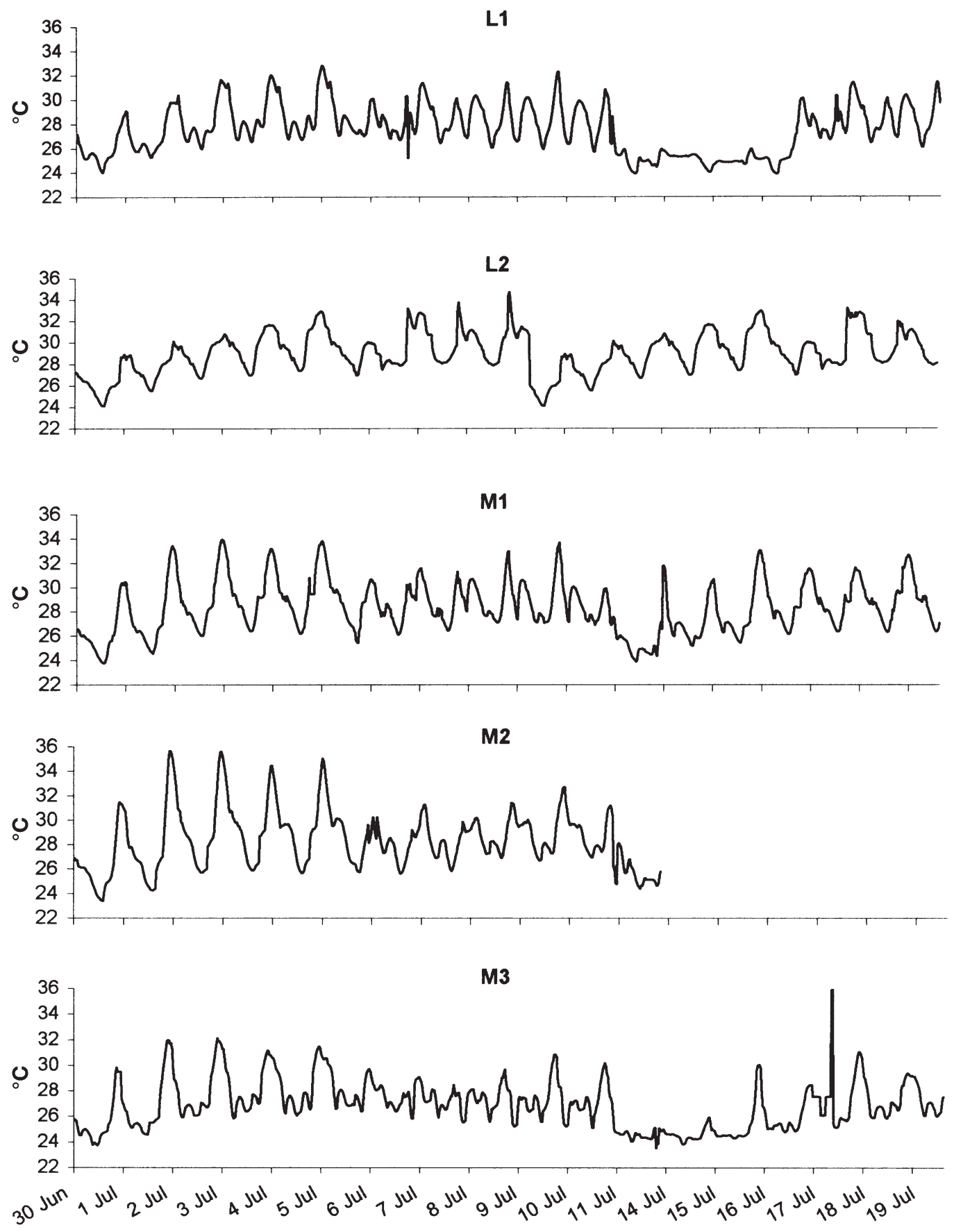

Fig. 2. Temperature recorded at 30 min intervals at each enclosure site 
duration of hyperoxic events among sites (ANOVA, $\mathrm{p}=0.019$ ), ranging from 1.0 (L2) to 5.4 (M1) h.

\section{Survival}

Summer flounder recovery ranged from 0 to $100 \%$ for individual cages, with site averages ranging from 0 to $81 \%$ (Table 4 ). There was a significant difference in recovery between sites (ANOVA, p < 0.003). Comparison of initial and final length frequencies for individual fish did not indicate that fish loss was size-specific (Kolmogorov-Smirnov test, $\mathrm{p} \leq 0.05$ ). In the 2 additional enclosure experiments conducted as a result of zero survival at Site M2, no fish or their remains were recovered after the $24 \mathrm{~h}$ period.

\section{Growth rate}

Mean final length among sites ranged from $53 \pm 1.26$ to $58 \pm 2.12 \mathrm{~mm} \mathrm{TL}$, and mean final weight from $1.58 \pm$

Table 2. Means, SD, variances, number of measurements (n), minimum and maximum temperature, dissolved oxygen (DO), salinity and $\mathrm{pH}$ measured every $30 \mathrm{~min}$ from 29 June to 22 July 1999 (M2 data from 29 June to 12 July 1999 only) at each enclosure site

\begin{tabular}{|c|c|c|c|c|c|}
\hline \multirow{2}{*}{ Parameter } & \multicolumn{5}{|c|}{ Site } \\
\hline & L1 & L2 & M1 & M2 & M3 \\
\hline \multicolumn{6}{|l|}{ Temp. $\left({ }^{\circ} \mathrm{C}\right)$} \\
\hline Mean & 27.5 & 29.0 & 28.4 & 28.3 & 26.9 \\
\hline $\mathrm{SD}$ & 2.0 & 2.0 & 2.2 & 2.4 & 1.9 \\
\hline Variance & 4.2 & 3.9 & 4.7 & 5.9 & 3.5 \\
\hline $\mathrm{n}$ & 1097 & 1011 & 847 & 572 & 998 \\
\hline Min. & 23.9 & 24.1 & 23.8 & 23.4 & 23.5 \\
\hline Max. & 32.8 & 34.7 & 34.0 & 35.7 & 36.2 \\
\hline \multicolumn{6}{|l|}{$\mathrm{DO}\left(\mathrm{mg} \mathrm{l}^{-1}\right)$} \\
\hline Mean & 6.9 & 4.6 & 6.2 & & 4.8 \\
\hline $\mathrm{SD}$ & 1.5 & 1.4 & 1.7 & & 1.6 \\
\hline Variance & 2.3 & 1.9 & 2.8 & & 2.6 \\
\hline $\mathrm{n}$ & 1097 & 1011 & 847 & & 998 \\
\hline Min. & 2.9 & 1.3 & 1.8 & & 0.0 \\
\hline Max. & 10.4 & 10.9 & 9.8 & & 7.9 \\
\hline \multicolumn{6}{|c|}{ Salinity (ppt) } \\
\hline Mean & 25.4 & 23.1 & 29.8 & 27.1 & 25.7 \\
\hline $\mathrm{SD}$ & 9.6 & 10.1 & 3.4 & 2.3 & 3.3 \\
\hline Variance & 92.9 & 101.6 & 11.6 & 5.3 & 11.0 \\
\hline $\mathrm{n}$ & 1097 & 1011 & 847 & 572 & 998 \\
\hline Min. & 0.1 & 1.5 & 6.9 & 3.4 & 11.7 \\
\hline Max. & 36.4 & 34.9 & 36.4 & 32.8 & 36.3 \\
\hline \multicolumn{6}{|l|}{$\mathrm{pH}$} \\
\hline Mean & 7.8 & 7.2 & 7.8 & 7.8 & 7.7 \\
\hline $\mathrm{SD}$ & 0.3 & 0.2 & 0.3 & 0.3 & 0.2 \\
\hline Variance & 0.1 & 0.1 & 0.1 & 0.1 & 0.0 \\
\hline $\mathrm{n}$ & 1097 & 1011 & 847 & 572 & 998 \\
\hline Min. & 7.0 & 6.8 & 7.0 & 7.2 & 7.2 \\
\hline Max. & 8.3 & 8.1 & 8.5 & 8.3 & 8.0 \\
\hline
\end{tabular}

0.14 to $2.27 \pm 0.32 \mathrm{~g}$ (Table 1 ). Mean growth rates among sites ranged from $-0.49 \pm 1.79$ to $2.04 \pm 0.56 \%$ in weight, and from $0.21 \pm 0.18$ to $0.50 \pm 0.16 \%$ in length (Table 1). The statistical power of the fixedeffects nested ANOVA was 0.89. There was no significant effect of site on mean growth rate $(p=0.31)$. The effect of initial weight on growth rates was significant ( $p=0.0007)$, with smaller fish showing somewhat higher growth rates than larger fish. However, since mean fish size was consistent among cages and sites, it is unlikely that initial weights altered the effect of site on mean growth rates. The site $\times$ initial weight interaction was marginally significant ( $p=0.04$ ), most likely due to the effect of initial weight rather than site on final growth rates. Growth rates among cages at each site were highly variable, with standard deviations ranging from -1.76 to 2.76 (means from -0.49 to 2.04 ).

\section{Production}

Site M2 was omitted from the production analysis since no fish survived at that site. Among the remaining sites, mean production values ranged from $0.70 \pm 0.06$ to $6.38 \pm 3.35$. There were no significant differences in production estimates among sites (ANOVA, $p=0.46)$.

Table 3. Number (n) and duration (h) of hypoxic (DO $\leq 2 \mathrm{mg} \mathrm{l}^{-1}$ ) and hyperoxic ( $D O \geq 110 \%$ saturation) events at enclosure sites in and around Masonboro Island during the enclosure study (29 June to July 1999). na: not available

\begin{tabular}{|lclcc|}
\hline Parameter & \multicolumn{4}{c|}{ Site } \\
& L1 & L2 & M1 & M3 \\
\hline Hypoxic events & & & & \\
Min. & na & 0.5 & 1 & 0.5 \\
Max. & na & 6 & 6 & 17 \\
Avg. & na & 2.4 & 4.4 & 3.3 \\
n & 1 & 24 & 7 & 22 \\
Hyperoxic events & & & & \\
Min. & 0.5 & 0.5 & 0.5 & 0.5 \\
Max. & 16.5 & 1.5 & 16 & 2.5 \\
Avg. & 5.2 & 1.0 & 5.4 & 1.3 \\
$\mathrm{n}$ & 19 & 10 & 22 & 5 \\
\hline
\end{tabular}

Table 4. Paralichthys dentatus. Percent recovery from cages and sites at end of 3 wk enclosure study (at Sites L1, L2, M1, M2 and M3) and 2 additional enclosure trials at M2 (M2-2, M2-3)

\begin{tabular}{|lccccccc|}
\hline Cage & & \multicolumn{7}{c|}{$\begin{array}{c}\text { Site } \\
\text { L2 }\end{array}$} & M2 & M1 & M2-3 & M3 \\
\hline 1 & 100 & 100 & 100 & 0 & 0 & 0 & 75 \\
2 & 50 & 75 & 0 & 0 & 0 & 0 & 50 \\
3 & 75 & 50 & 25 & 0 & 0 & 0 & 75 \\
4 & 100 & 50 & 0 & 0 & 0 & 0 & 75 \\
Mean & 81 & 69 & 31 & 0 & 0 & 0 & 69 \\
\hline
\end{tabular}




\section{Stomach contents}

Summer flounder were removed from cages within $24 \mathrm{~h}$ of the last feeding. Wild prey items were prevalent in fish stomachs at each of the sites at the time of removal from enclosures. Hatchery food was completely absent. There were no differences among sites in the levels of gut fullness of juvenile summer flounder $\left(\chi^{2}>0.05\right)$, with $60 \%$ of all fish having some amount of food present in their stomachs.

\section{DISCUSSION}

Growth rates similar to those in this study were observed in juvenile summer flounder reared at temperatures from 18 to $26^{\circ} \mathrm{C}\left(0.4\right.$ and $0.6 \mathrm{~mm} \mathrm{~d}^{-1}$; J. S. Burke unpubl. data; 0.0 to $0.6 \mathrm{TL} \mathrm{mm} \mathrm{d}^{-1}$ our study). However, it is difficult to compare growth rates reported for juvenile summer flounder and other flatfishes in similar studies (Malloy \& Targett 1991, Reichert \& Van der Veer 1991, Roundtree \& Able 1992,
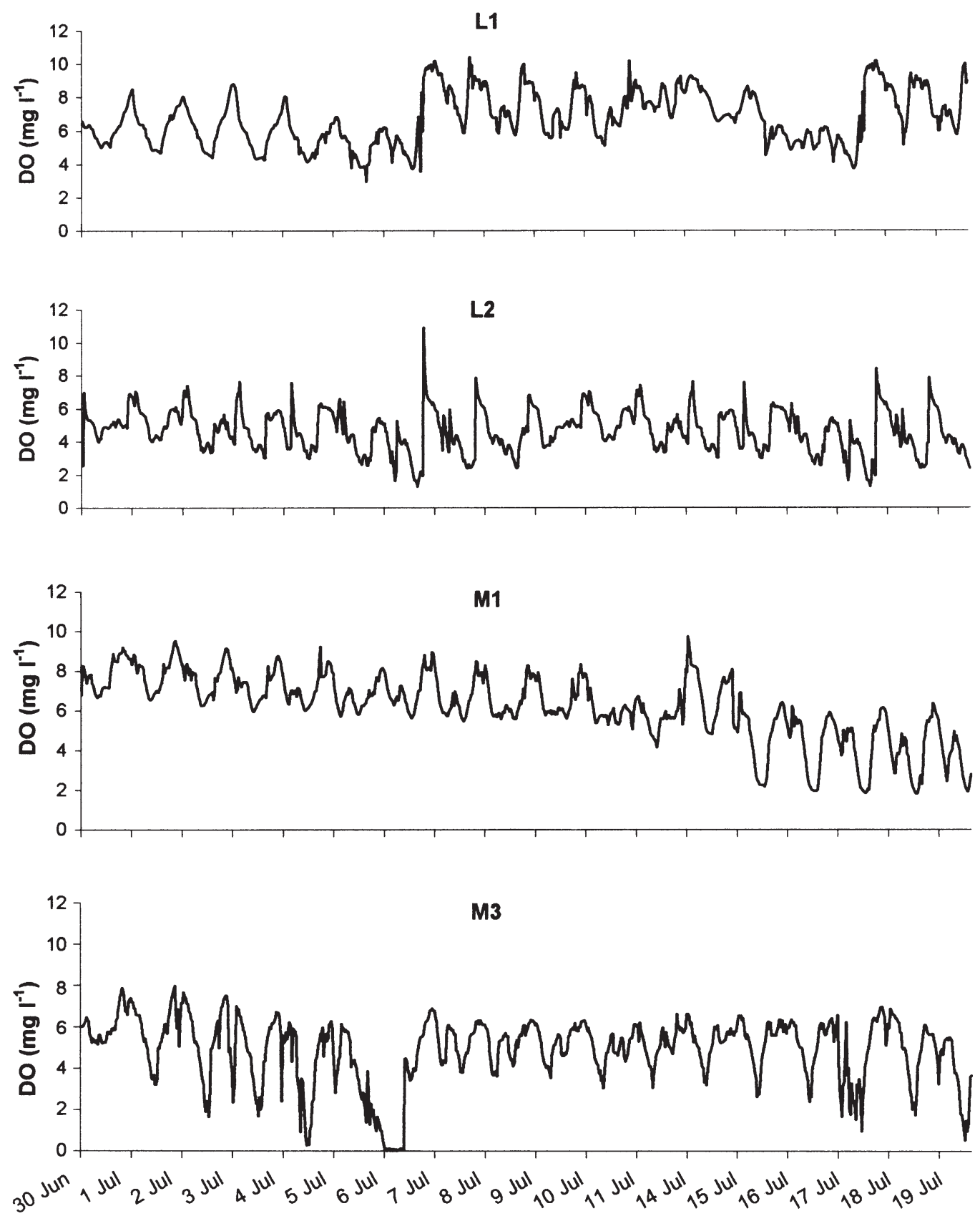

Fig. 3. Dissolved oxygen (DO) recorded at 30 min intervals at each enclosure site. (Data not available for M2) 
Sogard 1992, Keefe \& Able 1994, Guindon \& Miller 1995, Davis 1998, Phelan et al. 2000) with those of summer flounder in this study because of differences in methodology (laboratory vs. field, caged vs. wild, feeding vs. no feeding, predator controls, habitat type), geographic area and species used.

Although the fish used in this study were obtained from hatchery-reared New Hampshire brood stock, we do not believe their origin affected the experimental results, specifically their ability to grow and survive in water temperatures higher than they would experience in more northern waters. Prior to the enclosure experiment, all fish were held in a common tank receiving water directly from the intracoastal waterway and were acclimated for several weeks to the same ambient abiotic conditions. Additionally, we ran 3 separate prelim-
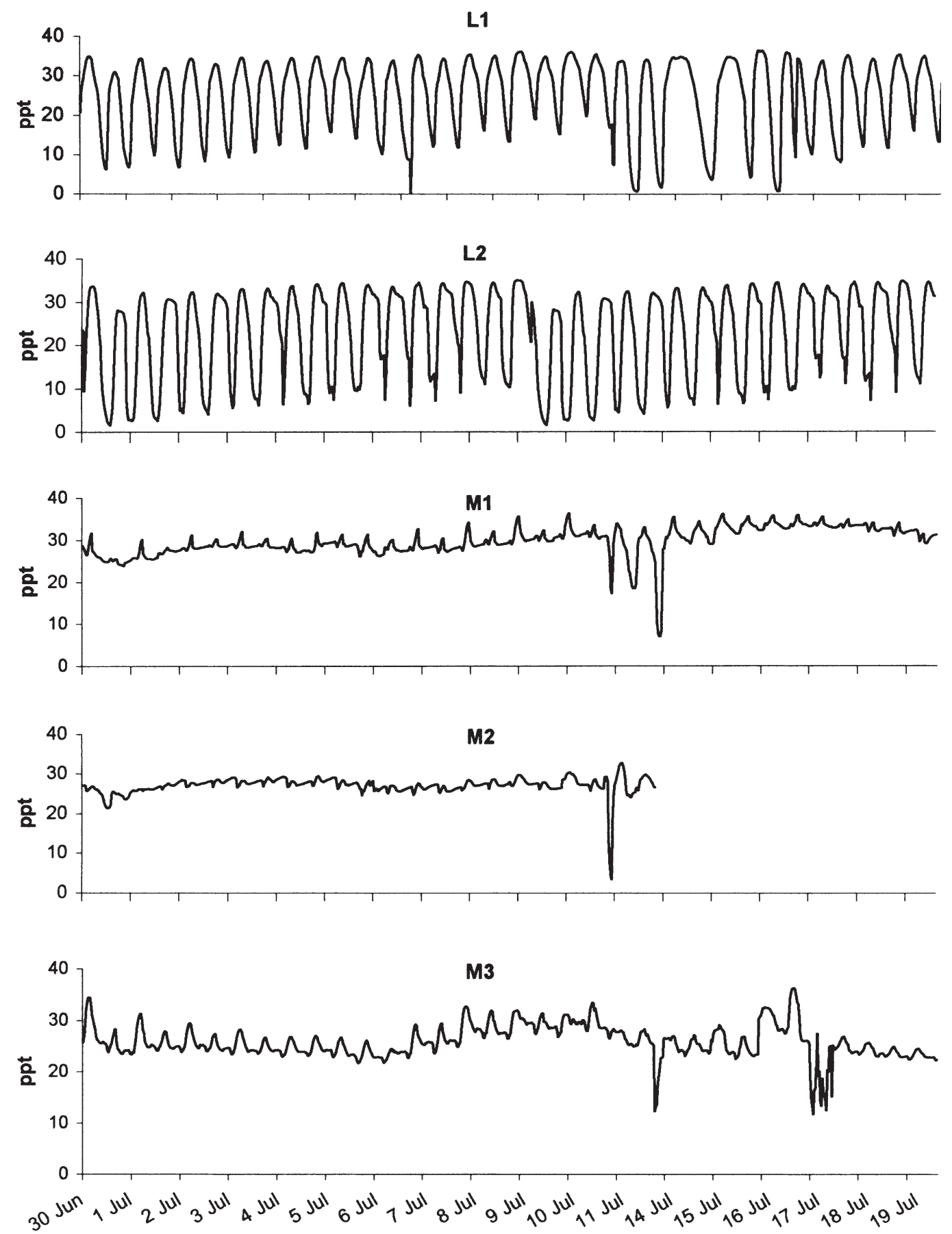

Fig. 4. Salinity recorded at 30 min intervals at each enclosure site 
inary enclosure experiments during summer 1998 using hatchery-reared fish from North Carolina brood stock. Although certain experimental parameters were different from those in the 1999 enclosure study, the abiotic conditions were similar. In experiments run during a similar time period in 1998, summer flounder recovery ranged from 0 to $100 \%$ for individual cages, i.e. the same as in 1999. Mean growth rates among sites for
North Carolina summer flounder ranged from $-0.57 \pm$ 0.63 to $0.14 \pm 0.49 \%$, compared to $0.49 \pm 1.79$ to $2.04 \pm$ $0.56 \%$ in 1999. Individual growth rates ranged from -1.59 to $1.63 \%$ for fish in 1998 , compared to -1.75 to $3.71 \%$ in 1999. Similarities in mortality and growth rates in the North Carolina fish indicate that the New Hampshire fish were not compromised in their ability to grow and survive in North Carolina waters.
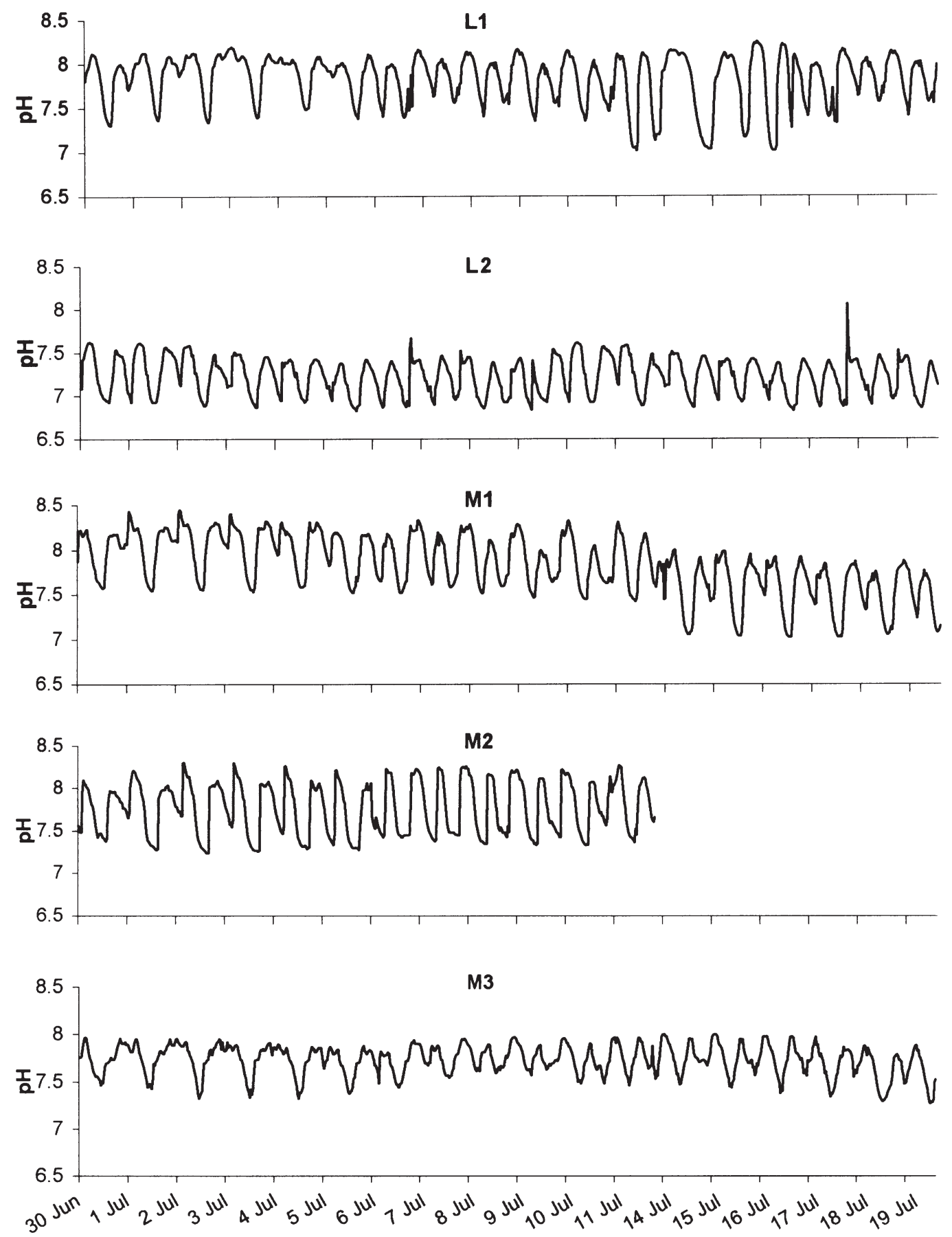

Fig. 5. pH recorded at 30 min intervals at each enclosure site 
Variability in growth rates both within and among sites during our study was high. Individual variation in growth is common among juvenile flatfishes, but the variability we observed is among the highest reported for field enclosure experiments (e.g. Sogard 1992, Guindon \& Miller 1995, Kellison 2000). Our enclosure experiments differed in controlling for food availability differences among sites, which should have reduced variability. We believe the high variability in our growth rates may be the result of a wide range of individual responses to abiotic characteristics as opposed to other habitat factors. Such variability may be a normal adaptive trait of a species occupying an environmentally variable habitat (Meise et al. 2003).

Many studies have documented the effect of abiotic conditions on juvenile flatfish growth rates. Changes in temperature impact feeding rates, metabolism and, as a result, growth potential (Malloy \& Targett 1991, Gibson 1994). Continuous or fluctuating exposure to reduced oxygen levels can reduce growth rates (Bejda et al. 1992, Taylor \& Miller 2001). Salinity mainly affects the distribution and movement of juvenile fishes (Gibson 1994), but may have a limited effect on growth rates (Malloy \& Targett 1991, Gibson 1994, Miller et al. 2000). However, such studies are often laboratorybased, single-parameter experiments. Attempts to determine growth responses of an organism based on a single parameter can mask the fact that several abiotic factors interact to elicit a response.

Abiotic conditions measured during this study were typical of southeastern US estuarine systems during the summer (Wenner \& Sanger 1998, Wenner et al. 2001). Rapid tidally driven fluctuations occurred in all parameters, often over short time periods. Estuarinedependent juvenile fishes are well adapted to such dynamic conditions and adjust rapidly to certain sudden changes (Moser \& Gerry 1989, Moser \& Miller 1994). With increasing technological capabilities, these changes can be monitored at more frequent time intervals, but are these time scales physiologically relevant? How are statistically versus biologically significant differences determined? Research is required to identify the time scales at which to measure critical variables (Wenner \& Geist 2001). It is possible that what appear to be highly significant differences in abiotic factors are not physiologically relevant in terms of growth to the organisms experiencing them.

The recovery rates for summer flounder in this study differed significantly between sites. The cages were completely enclosed, and checked frequently for openings; we therefore believe low recovery was due to mortality within the cages and not to escape. Extreme abiotic conditions and inside predation may have played a role in the mortality responsible for low recovery. Under some conditions, flatfishes can suffer marked mortality from lethal high temperatures (Berghahn et al. 1993), and this was most likely the cause for zero recovery at Site M2 during all 3 enclosure experiments. During the first enclosure experiment at Site $\mathrm{M} 2$, temperatures peaked around $35^{\circ} \mathrm{C}$ for 4 consecutive days; during the third deployment, temperatures increased from 33 to $35^{\circ} \mathrm{C}$ in $45 \mathrm{~min}$, and continued to rise to $37^{\circ} \mathrm{C}$. No other site experienced these temperature patterns or levels. Hypoxia also occurred during the second and third cage deployments at Site M2, for periods of 3 and $5.5 \mathrm{~h}$, respectively. The results of these additional trials indicate that fish in these cages died from a combination of extreme abiotic conditions (temperature and DO), and were then rapidly decomposed or consumed by small scavengers, such as amphipods, that were able to move through the mesh. Similar results were observed in comparable caging studies by Able (1999) and Phelan et al. (2000).

In summary, differences in temperature, DO, salinity and $\mathrm{pH}$ occurred among all sites during the study. Differences in growth rates, however, were not detected among those sites with surviving fish. We conclude that Sites L1, L2, M1 and M3 were of equal value in terms of growth potential for juvenile Paralichtys dentatus during the summer. In contrast, Site M2 comprised a poor habitat, since all fish at this site died. The production analysis supports these results. There were no significant differences in either mortality or growth rates among sites with surviving fish, and therefore no differences in production.

Although growth rates among sites were not statistically different, there was a trend toward slightly higher growth in mainland creeks than in barrier island creeks. Additionally, mortality occurred more often in barrier island enclosures than in mainland enclosures, with total mortality occurring repeatedly at 1 site (M2). This pattern seems to contradict the convention that juvenile summer flounder preferentially occupy higher salinity habitats near the mouths of estuaries (Burke et al. 1991, Able \& Kaiser 1994, Burke 1995, Able \& Fahay 1998).

The results of this study indicate that basic abiotic conditions, at the levels and durations prevalent within a southeastern US estuary during summer, have little discernible impact on juvenile summer flounder growth over short time periods, but may influence survival. Duchon (2001) also did not detect growth differences in caged juvenile summer flounder among 4 North Carolina estuaries. Ross (2003) found no significant growth differences for 3 dominant estuarine species across several North Carolina estuaries; however, he did note survival differences. Although models predict that basic abiotic factors should affect groth rates of estuarine fishes (Miller et al. 2000), several field (Duchon 2001, Ross 2003) and laboratory (Moser \& 
Miller 1994) studies have not detected this. Differences in fish growth across estuarine habitats are known, but may be associated more with food resources, vegetation or other habitat characteristics than with abiotic conditions (Sogard 1992, Guindon \& Miller 1995). Abiotic conditions can affect many aspects of fish ecology (e.g. distributions, Burke et al. 1991, Wannamaker \& Rice 2000; physiology, Ross et al. 2001, Taylor \& Miller 2001; survival, Malloy \& Targett 1991, 1994); however, in fishes adapted to a highly variable environment, we expect a corresponding high degree of life history plasticity, as reflected by the growth variability recorded in this study.

Acknowledgements. This research was supported by Grant NA86RG0036 from the National Sea Grant College Program, National Oceanographic and Atmospheric Administration, to the North Carolina Sea Grant College Program under the direction of Dr. J. M. Miller. The North Carolina National Estuarine Research Reserve provided laboratory and office space, as well as equipment and personnel resources necessary to the project. Thanks to Dr. D. B. Eggleston for his support and advice throughout the project, and to Dr. M. Davidian for statistical assistance. D. Darazsdi, C. Harmelink, K. Hill, J. Karp, T. Necaise, B. Railo, J. Staton and D. Tenney provided valuable help in the field. Thanks to M. Lizotte for assistance with YSI dataloggers and to J. Ott for creating the site map. J. Bichy, B. Burke, R. Jackson and J. C. Taylor provided valuable support and suggestions throughout this project.

\section{LITERATURE CITED}

Able KW (1999) Measures of juvenile fish habitat quality: examples from a national estuarine research reserve. Am Fish Soc Symp 22:134-147

Able KW, Fahay MP (1998) The first year in the life of estuarine fishes in the Middle Atlantic Bight. Rutgers University Press, New Brunswick, NJ

Able KW, Kaiser SC (1994) Synthesis of summer flounder habitat parameters. NOAA coastal ocean program decision analysis series 1. NOAA Coastal Ocean Office, Silver Spring, MD

Bejda AJ, Phelan BA, Studholme AL (1992) The effect of dissolved oxygen on the growth of young-of-the-year winter flounder, Pseudopleuronectes americanus. Environ Biol Fish 34:321-327

Berghahn R, Bullock AM, Karakiri M (1993) Effects of solar radiation on the population dynamics of juvenile flatfish in the shallows of the Wadden Sea. J Fish Biol 42:329-345

Burke JS (1995) Role of feeding and prey distribution of summer and southern flounder in selection of estuarine nursery habitats. J Fish Biol 47:355-366

Burke JS, Miller JM, Hoss DE (1991) Immigration and settlement pattern of Paralichthys dentatus and P. lethostigma in an estuarine nursery ground, North Carolina, USA. Neth J Sea Res 27:393-405

Davis DD (1998) The role of temperature on somatic and otolith growth of juvenile southern flounder (Paralichthys lethostigma) in North Carolina estuaries. Master's thesis, North Carolina State University, Raleigh, NC

Duchon KA (2001) Experimental evaluation of juvenile fish habitat: field measures of fish performance and ecophysio- logical model predictions. Master's thesis, North Carolina State University, Raleigh, NC

Diaz RJ, Rosenberg R (1995) Marine benthic hypoxia: a review of its ecological effects and the behavioural responses of benthic macrofauna. Oceanogr Mar Biol Annu Rev 33:245-303

Gibson RN (1994) Impact of habitat quality and quantity on the recruitment of juvenile flatfishes. Neth J Sea Res 32: 191-206

Guindon KY, Miller JM (1995) Growth potential of juvenile southern flounder, Paralichthys lethostigma, in low salinity nursery areas of Pamlico Sound, North Carolina, USA. Neth J Sea Res 34:89-100

Keefe ML, Able KW (1994) Contributions of abiotic and biotic factors to settlement in summer flounder, Paralichthys dentatus. Copeia 1994(2):458-465

Kellison GT (2000) Evaluation of stock enhancement potential for summer flounder (Paralichthys dentatus): an integrated laboratory, field and modeling study. PhD dissertation, North Carolina State University, Raleigh, NC

Malloy KD, Targett TE (1991) Feeding, growth and survival of juvenile summer flounder Paralichthys dentatus: experimental analysis of the effects of temperature and salinity. Mar Ecol Prog Ser 72:213-223

Malloy KD, Targett TE (1994) Effects of ration limitation and low temperature on growth, biochemical condition, and survival of juvenile summer flounder from two Atlantic Coast nurseries. Trans Am Fish Soc 123:182-193

Meise, CJ, Johnson DL, Stehlik LL, Manderson J, Shaheen P (2003) Growth rates of juvenile winter flounder under varying environmental conditions. Trans Am Fish Soc 132:335-345

Miller JM, Neill WH, Duchon KA, Ross SW (2000) Ecophysiological determinants of secondary production in salt marshes: a simulation study. In: Weinstein MP, Kreeger DA (eds) Concepts and controversies in tidal marsh ecology. Kluwer Academic, Amsterdam, p 315-332

Moser ML, Gerry LR (1989) Differential effects of salinity changes on two estuarine fishes, Leiostomus xanthurus and Micropogonias undulatus. Estuaries 12:35-41

Moser ML, Miller JM (1994) Effects of salinity fluctuation on routine metabolism of juvenile spot, Leiostomus xanthurus. J Fish Biol 45:335-340

Neill WH, Gallaway BJ (1989) 'Noise' in the distributional responses of fish to environment: an exercise in deterministic modeling motivated by the Beaufort Sea experience. Biol Pap Univ Alsk 24:123-130

Peters DS, Angelovic JW (1973) Effect of temperature, salinity and food availability on growth and energy utilization of juvenile summer flounder, Paralichthys dentatus. In: Nelson DJ (ed) Radionucleides in ecosystems, Vol 1. Proceedings of the National Symposium on Radioecology, Oak Ridge, Tennessee, 1971. United States Atomic Energy Commission, Oak Ridge, TN, p 545-554

Phelan BA, Goldberg R, Bejda AJ, Pereira J and 5 others (2000) Estuarine and habitat-related differences in growth rates of young-of-the-year winter flounder (Pseudopleuronectes americanus) and tautog (Tautoga onitis) in three northeastern estuaries. J Exp Mar Biol Ecol 247:1-28

Reichert MJM, Veer HW Van der (1991) Settlement, abundance, growth and mortality of juvenile flatfish in a subtropical tidal estuary (Georgia, USA). Neth J Sea Res 27: 375-391

Ross SW (2003) The relative value of different estuarine nursery areas in North Carolina for transient juvenile marine fishes. Fish Bull NMFS Fish Bull 101:384-404

Ross SW, Dalton DA, Kramer S, Christensen BL (2001) Physiological (antioxidant) responses of estuarine fishes to vari- 
ability in dissolved oxygen. Comp Biochem Physiol C 130: 289-303

Roundtree RA, Able KW (1992) Foraging habits, growth and temporal patterns of salt-marsh creek habitat use by young-of-the year summer flounder in New Jersey. Trans Am Fish Soc 121:765-776

Sogard SM (1992) Variability in growth rates of juvenile fishes in different estuarine habitats. Mar Ecol Prog Ser 85:35-53

Summers JK, Engle VD (1993) Evaluation of sampling strategies to characterize dissolved oxygen conditions in northern Gulf of Mexico estuaries. Environ Monit Assess 24: $219-229$

Szedlmayer ST, Able KW, Roundtree RA (1992) Growth and temperature-induced mortality of young-of-the-year summer flounder (Paralichthys dentatus) in southern New Jersey. Copeia 1992(1):120-128

Taylor JC, Miller JM (2001) Physiological performance of juvenile southern flounder, Paralichthys lethostigma (Jordan \& Gilbert, 1884), in chronic and episodic hypoxia. J Exp Mar Biol Ecol 258:195-214

Thurman HV (1987) Essentials of oceanography, 2nd edn. Merrill, Columbus, $\mathrm{OH}$

Van der Veer H, Berghahn R, Rijnsdorp AS (1994) Impact of juvenile growth on recruitment in flatfish. Neth J Sea Res

Editorial responsibility: Kenneth Heck (Contributing Editor), Dauphin Island, Alabama, USA
32:153-173

Wannamaker CM, Rice JA (2000) Effects of hypoxia on movements and behavior of selected estuarine organisms from the southeastern United States. J Exp Mar Biol Ecol 249: 45-163

Wenner EL, Geist M (2001) The National Estuarine Research Reserve's program to monitor and preserve estuarine waters. Coast Manag 29:1-17

Wenner EL, Holland AF, Sanger DM (1998) Assessing shortterm variability in dissolved oxygen and other water quality variables in shallow estuarine habitats. Ocean Community Conference Proceedings, November 16-19, Vol 2. Washington, DC, p 802-806

Wenner EL, Holland AF, Arendt MD, Chen Y, Edwards D, Miller C, Meece M, Caffrey J (2001) A synthesis of water quality data from the National Estuarine Research Reserve's system-wide monitoring program. Final Report to US Department of Commerce, National Ocean Service, Grant NA97OR0209 with Cooperative Institute for Coastal and Estuarine Environmental Technology. Department of Commerce, Washington, DC, p 1-274

Wooten RJ (1992) Fish ecology. Chapman \& Hall, New York Zar JH (1999) Biostatistical analysis, 4th edn. Prentice Hall, Upper Saddle River, NJ

Submitted: March 25, 2003; Accepted: May 26, 2004

Proofs received from author(s): December 27, 2004 